\title{
TALAJFAUNISZTIKAI- ÉS ÖKOLÓGIAI VIZSGÁLATOK ALFÖLDI RELIKTUM HOMOKI TÖLGYESEKBEN ÉS A HELYÜKÖN LÉTESÍTETT IDEGENHONOS FAÁLLOMÁNYOKBAN
}

\author{
Palkó Ákos ${ }^{1}$, Ónodi Gábor ${ }^{2}$, Rédei Tamás ${ }^{2}$ és Winkler Dániel ${ }^{1}$ \\ ${ }^{1}$ Soproni Egyetem, Erdömérnöki Kar, Sopron \\ 20̈kológiai Kutatóközpont, Ökológiai és Botanikai Intézet, Vácrátót
}

\begin{abstract}
KIVONAT
Jelen kutatás célja a kiskunsági reliktum homoki tölgyesek és a helyükön létesitett idegenhonos (nemes nyár, feketefenyö, akác) ültetvények Collembola faunisztikai és ökológiai vizsgálata volt. A talajmintákat az emlitett négy állománytípusból gyüjtöttük, három ismétlésben. Összesen 3033 Collembola egyed válogatása és határozása történt meg, melynek során 56 fajt sikerült kimutatnunk. A kumulált fajszám legmagasabb értéke (47 faj) az őshonos homoki tölgyesre volt jellemző, míg ennek kevesebb, mint fele fordult elö a nemes nyár (19), fekete fenyő (22) és akác (23) ültetvényekben. A talajparaméterek Collembola közösségekre gyakorolt hatását vizsgálva pozitiv összefüggést találtunk a $\mathrm{C} / \mathrm{N}$ arány és az ugróvillások abundanciája ( $r=0,71 ; F=10,44, p<0,05)$, valamint a talajok humusztartalma és a Collembola közösségek diverzitása között $(r=0,61, F=5,98, p<0,05)$. A kanonikus korreszpondencia analízis a homoki tölgyesek és az idegenhonos fafajú ültetvények elkülönülését mutatta az elsősorban a pH és a humusztartalom által magyarázott tengely mentén.
\end{abstract}

Kulcsszavak: ugróvillás-közösségek, diverzitás, idegenhonos ültetvények, talajdegradáció

\section{SOIL ECO-FAUNISTIC STUDY IN LOWLAND RELICT STEPPE OAK FORESTS AND IN REPLACEMENT NON-NATIVE TREE PLANTATIONS}

\begin{abstract}
The aim of the present study was to investigate the soil Collembola communities in the relict closed lowland steppe oak forests in the Kiskunság. Further goal was to carry out comparative analyses of Collembola community diversity and abundance between the autochton oak forests and the replacement allochton plantations of non-native tree species (hybrid poplar, black pine, black locust). Soil samples were taken from the above mentioned four forest habitats in three replicates. A total of 3,033 specimens belonging to 56 Collembola species were collected and identified. Species richness was the highest (47) in the autochton steppe oak forests. In comparison, number of species was less than a half in the hybrid poplar (19), black pine (22) and black locust (23) plantations. Regarding the relationships between the measured soil parameters and Collembola communities, positive correlations were found between the $\mathrm{C} / \mathrm{N}$ ratio and Collembolan abundance $(r=0.71$; $\mathrm{F}=10.44, \mathrm{p}<0.05)$ and between soil organic matter content and Collembola diversity $(r=0.61, F=5.98, p<0.05)$. The canonical correspondence analysis $(\mathrm{CCA})$ well separated the steppe oak forests and the non-native plantations along the axis mostly determined by soil pH and carbon content.
\end{abstract}

Keywords: Collembola communities, diversity, allochthonous plantations, soil degradation 


\section{BEVEZETÉS}

Hazánk nagyalföldi területén egykoron magas részarányt képviseltek a homoki tölgyesek. Területcsökkenésük egyik fő oka a vízrendezéseket követő talajvízszint-csökkenés volt. A szárazodó makroklíma hatására az átlagos talajvízszint tovább csökkent, s a víz egyes növények számára elérhetetlen mélységbe húzódott vissza (Bartha 2001). A másik fő tényező az ember általi gazdasági döntések sorozata volt, amely a fafajválasztásban, az erdők tarvágásos használati módjában nyilvánult meg. Olyan fafajok állományaival kívánták helyettesíteni a homoki tölgyesek zárt és nyílt típusait, amelyek jobban kihasználják az adott termőhelyi feltételeket, vágásfordulójuk rövidebb, vagy kevesebb tápanyaggal is beérik, mégis hasonló minőségű és értékű fát adnak. Származékerdőket hoztak létre fehérnyárral, továbbá kultúrerdőket létesítettek helyükön akác, fekete-, erdei-, simafenyő, feketedió fafajokkal, illetve nemes nyár fajtákkal (Lesznyák 1993). Évtizedek munkája nyomán mára odáig jutott a helyzet, hogy a természetes homoki tölgyes társulások foglalják el a legkisebb részt hazánk természetes eredetü, erdővel borított területéből (Molnár \& Kun 2000).

Az ilyen markáns átalakítások a talajra és a talajfaunára is hatással vannak. Az idegenhonos, ültetvényszerű faállományok biodiverzitása - így talajfaunája is - eredendően szegényebb, mint az őshonos fafajok alkotta állományoké (Lindenmayer et al 2003). Hazai viszonylatban ezt a megállapítást főként az akác, feketefenyő, erdei fenyő és nemesnyár monokultúrák esetében igazolták (Traser \& Csóka 2001, Traser 2003, Winkler \& Tóth 2012), de ugyanez elmondható bármely egzóta ültetvényre Európa szerte (Klimetzek 1992), annak ellenére, hogy meglehetősen kevés az olyan vizsgálat, amely az idegenhonos fafajok hatását értékeli a talajlakó ugróvillás faunára nézve. Spanyolországban és Portugáliában elsősorban a kiterjedt eukaliptusz (Eucalyptus spp.) ültetvények jelentenek ilyen jellegü problémát. Eukaliptusz ültetvények, valamint nem őshonos tülevelü ültetvények talajfaunára gyakorolt hatását vizsgálva (Arbea \& Jordana 1985, Gama et al 1994, 1995, Sousa \& Gama 1994, Pinto et al 1997, Sousa et al 1997) azt mutatták ki, hogy a Collembola közösségek diverzitását leginkább az állomány alatt képződő avarréteg eltérő kémhatása, valamint ezen keresztül a talajparaméterek megváltozása csökkenti.

Az erdőterületeinken sok helyen napjainkban is zajló élőhelyátalakítás hatásának vizsgálata a talajfaunisztika aktuális kérdése. Jelen kutatás újszerüségét az adja, hogy ezekben a reliktum jellegü homoki tölgyesekben - egy dél-kiskunsági vizsgálat (Traser \& Csóka 2001) kivételével - nem történtek ilyen jellegü vizsgálatok, valamint hiányoznak az összehasonlító elemzések is az ültetvényszerű nemesnyár, akác és fenyő állományokkal.

\section{ANYAG ÉS MÓDSZER}

\section{Vizsgálati terület}

A vizsgálat célkitüzéseinek megfelelően a mintaterületeket kiskunsági autochton zárt homoki tölgyes (HTGY) állományokban, valamint a helyükre ültetett, allochton nemes nyár (NNY), feketefenyő (FF) és akác (A) ültetvényekben jelöltük ki Pusztavacs-Tatárszentgyörgy, Szabadszállás és Kunbaracs térségében. Törekedtünk a célfafaj magas elegyarányára, ezáltal a talajra gyakorolt hatás egzaktabb kimutatására. A mintavételezést három ismétlésben végeztük, egymástól jól elkülönülő helyszíneken (site-okon) (1. ábra). A négy vizsgált állománytípusból így 3-3 mintaterület jelöltünk ki. 


\section{Terepi mintavételezés módszere}

A talajparaméterek $(0-10 \mathrm{~cm})$ vizsgálatához minden mintaterületröl 5 talajmintát $(\mathrm{kb} .250 \mathrm{~g})$ gyüjtöttünk. Ugyanezen pontokon a talajlakó mezofauna vizsgálatokhoz szintén $5 \mathrm{db}$, egyenként $100 \mathrm{~cm}^{3}$ bolygatatlan talajmintát vettünk speciális mintavevő henger segítségével. Négy állománytípust vizsgálva, típusonként 3 mintavételi területtel, területenként 5 gyüijési ponttal összesen $60(4 \times 3 \times 5)$ db minta került gyüjtésre, 2019. április 26-án.

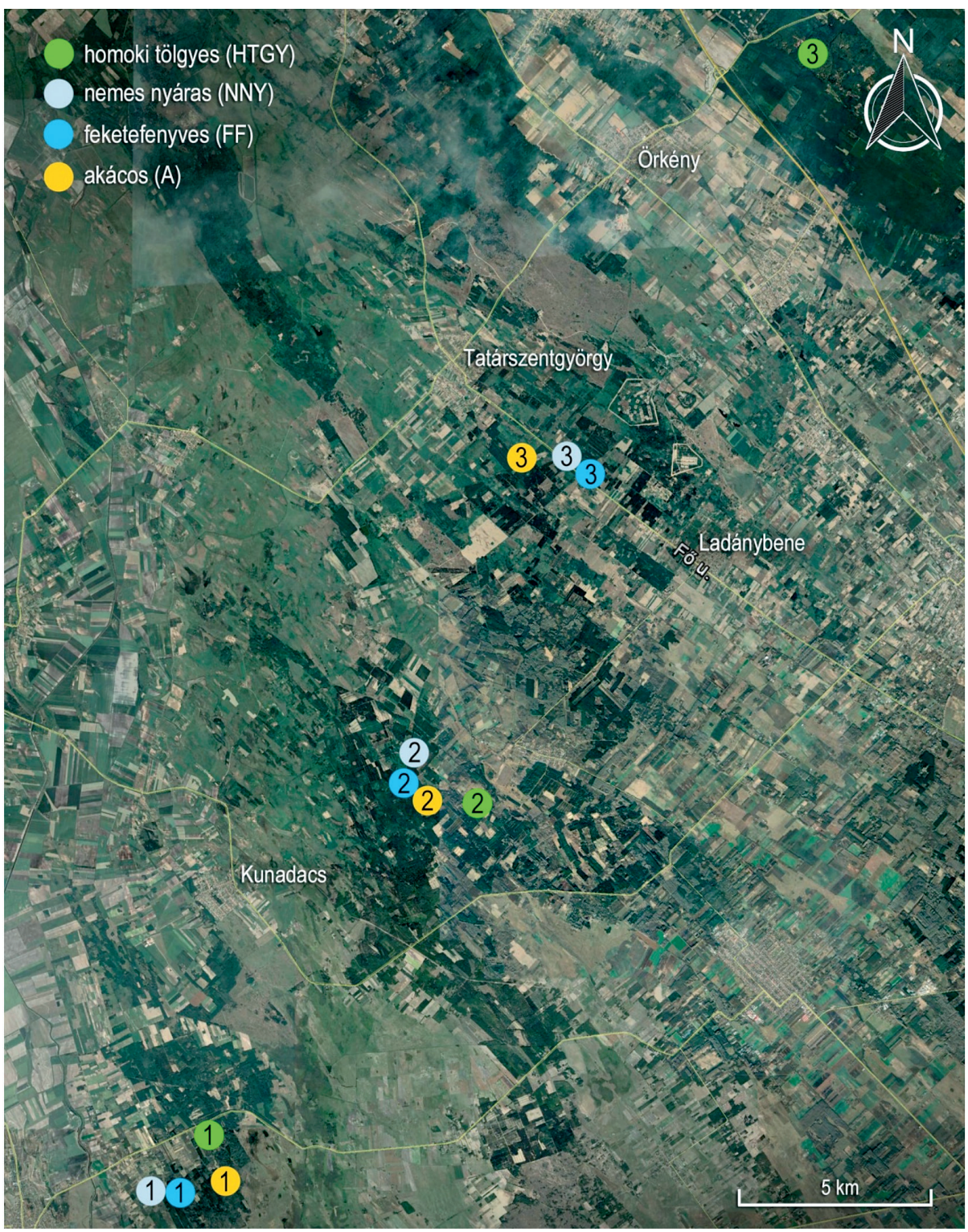

1. ábra: A mintavételi területek elhelyezkedése

Figure 1: Location of the study area - sampling sites (green circles: old-groth oak forests; grey circles: hybrid poplar plantations; blue circles: black pine plantations; yellow circles: black locust plantations) 


\section{Laboratóriumi vizsgálatok}

A légszárazra történő száritás után a talajmintákat összetörtük, majd 2,0 mm átméröjű szitán átszitáltuk. Minden mintából meghatároztuk a desztillált vizes $\left(\mathrm{pH}_{\mathrm{H} 2 \mathrm{O}}\right)$ és a kálium-kloridos $\left(\mathrm{pH}_{\mathrm{KCl}}\right) \mathrm{pH}$-t, a széntartalmat ( $\mathrm{C} \%$ ), Tyurin módszerrel, $\mathrm{K}_{2} \mathrm{Cr}_{2} \mathrm{O}_{7}$ és $\mathrm{H}_{2} \mathrm{SO}_{4}$ segítségével a humusztartalmat $(\mathrm{H} \%)$, Kjeldahl módszerrel a N-tartalmat (\%), az ammónium-laktát-oldható P- és K-tartalmat $\left(A L-\mathrm{P}_{2} \mathrm{O}_{5}, \mathrm{AL}-\mathrm{K}_{2} \mathrm{O}\right)$ és a mésztartalmat $\left(\mathrm{CaCO}_{3}\right)$ (Egnér et al 1960, Bacsó et al 1972, Buzás 1988).

Az ugróvillások kinyerése a talajmintákból Berlese-Tullgren elven (Tullgren 1918) müködő papírtölcséres futtatóval történt, szobahőmérsékleten, 10 napos várakozási idővel. A lefutott mintákból az ugróvillás egyedeket sztereómikroszkóp segítségével válogattuk le. Az egyedek leválogatása és számolása az élöhelynek megfelelő névvel ellátott, felcímkézett, 70\%-os etanolt tartalmazó fiolákba történt. Az egyes fajokat a föbb taxonómiai kulcsok (Deharveng 1982, Fjellberg 1980, 1998, Babenko et al 1994, Zimdars \& Dunger 1994, Weiner 1996, Jordana et al 1997, Pomorski 1998, Bretfeld 1999, Potapov 2001, Thibaud et al 2004, Jordana 2012) segítségével határoztuk meg. Az ugróvillások rendszertani áttekintésénél a magyar fauna besorolását (Dányi \& Traser 2008) vettük alapul.

\section{Az adatfeldolgozás és kiértékelés módszerei}

A közösségi-ökológiai elemzés során a fajszám, abundancia- és dominancia-viszonyok, fontosabb közösségi karakterisztikák - Shannon diverzitás (Shannon \& Weaver 1949), kiegyenlítettség (Pielou 1966), közösségi dominancia index (Krebs 1978) - segítségével végeztük el a vizsgált állományok összehasonlitó értékelését. A diverzitások összehasonlítását a Rényi-féle diverzitási profilok segítségével hasonlítottuk össze (Tóthmérész 1997). A talajkörnyezeti paraméterek és a Collembola fajok összefüggéseinek további feltárására kanonikus korreszpondencia analízist (CCA) végeztünk. Az ordináció alkalmazása során a talajkörnyezeti változókat az általuk lefedett variancia alapján válogattuk ki lépésenkénti kiválasztás alkalmazásával (ter Braak \& Šmilauer 2002). Emellett a kis létszámban (<5) elöforduló fajokat nem vontuk be az analízisbe, a bizonytalan kapcsolatok kiküszöbölése végett. Az elemzéseket a Past version 2.17b (Hammer et al 2001) statisztikai program segítségével végeztük el.

\section{EREDMÉNYEK}

\section{Talajparaméterek}

A mért talajparamétereket az 1. táblázat tartalmazza. A minták a pH értékek alapján a savanyútól a gyengén lúgos talajkémhatási kategóriákba esnek. A homoki tölgyesek mintái gyengén savanyúak, míg a nemes nyárasok gyengén lúgosak voltak. A feketefenyvesek és az akácosok mintái többnyire neutrális-gyengén lúgos kategóriába tartoznak, bár utóbbi állománytípusnál savanyú talaj is elöfordult. A homoki tölgyesekkel összehasonlítva az ültetvényszerü állományokat, egyedül a nemes nyárasok esetében mutatkozott szignifikáns eltérés a pH-t illetően.

A széntartalom, illetve humusztartalom a homoki tölgyesek mellett az akácosokban is magas volt, legalacsonyabb értékei a nemes nyárasokban adódtak (egyben szignifikáns különbséget is mutatva a homoki tölgyesekkel összehasonlítva).

A szemcseeloszlás hasonló volt, nem mutatkozott szignifikáns eltérés egyetlen frakció esetében sem. 
A nitrogéntartalom a vártnak megfelelően az akácosok esetében magasabbnak adódott, de szignifikáns eltérés nem volt megfigyelhető a homoki tölgyesekkel összehasonlítva (azonban a nemes nyárasok és feketefenyvesek talajának nitrogéntartalma szignifikánsan kisebb volt az akácosénál). A foszfor- és káliumtartalom tekintetében nem mutatkozott szignifikáns eltérés egy esetben sem.

1. táblázat: A vizsgált állományok talajparamétereinek átlagos értékei. A szignifikáns eltérések $(p<0,05)$ a kontrollnak tekintett homoki tölgyestöl vastagon szedve láthatók. HTGY - homoki tölgyes, NNY - nemes nyáras, FF - feketefenyves, A - akácos

Table 1: Soil parameters (mean \pm SE) in the studied forest types. Significant differences from the steppe oak forests, considered as control, are indicated in bold letter. HTGY - steppe oak forests, NNY - hybrid poplar, FF - Black pine, A - Black locust

\begin{tabular}{|c|c|c|c|c|}
\hline Talajparaméter & HTGY & NNY & FF & A \\
\hline $\mathrm{pH}\left(\mathrm{H}_{2} \mathrm{O}\right)$ & $6,10 \pm 0,26$ & $\mathbf{7 , 7 0 \pm 0 , 1 0}$ & $7,20 \pm 0,15$ & $6,57 \pm 0,59$ \\
\hline $\mathrm{pH}(\mathrm{KCl})$ & $5,87 \pm 0,38$ & $\mathbf{7 , 6 0} \pm \mathbf{0 , 0 6}$ & $7,10 \pm 0,14$ & $6,20 \pm 0,70$ \\
\hline $\mathrm{C} \%$ & $2,53 \pm 0,64$ & $\mathbf{0 , 7 0} \pm \mathbf{0 , 1 5}$ & $0,90 \pm 0,35$ & $3,10 \pm 0,62$ \\
\hline $\mathrm{H} \%$ & $4,13 \pm 1,11$ & $\mathbf{1 , 2 0} \pm \mathbf{0 , 2 6}$ & $1,60 \pm 0,60$ & $5,30 \pm 1,06$ \\
\hline $\mathrm{A} \%$ & $3,67 \pm 1,33$ & $3,00 \pm 1,15$ & $1,67 \pm 0,67$ & $3,67 \pm 0,67$ \\
\hline $\mathrm{I} \%$ & $4,00 \pm 1,15$ & $3,33 \pm 0,67$ & $4,67 \pm 1,33$ & $4,00 \pm 1,15$ \\
\hline $\mathrm{Fh} \%$ & $55,33 \pm 5,55$ & $59,33 \pm 5,49$ & $54,00 \pm 2,52$ & $53,33 \pm 5,93$ \\
\hline $\mathrm{Dh} \%$ & $37,00 \pm 7,23$ & $34,33 \pm 6,69$ & $39,67 \pm 2,33$ & $39,00 \pm 6,93$ \\
\hline $\mathrm{N} \%$ & $0,22 \pm 0,05$ & $0,07 \pm 0,02$ & $0,09 \pm 0,03$ & $0,37 \pm 0,07$ \\
\hline $\mathrm{AL}-\mathrm{P}_{2} \mathrm{O}_{5}(\mathrm{mg} / \mathrm{kg})$ & $11,97 \pm 1,97$ & $31,97 \pm 13,98$ & $22,87 \pm 8,87$ & $30,40 \pm 11,67$ \\
\hline $\mathrm{AL}-\mathrm{K}_{2} \mathrm{O}(\mathrm{mg} / \mathrm{kg})$ & $176,67 \pm 5,24$ & $149,00 \pm 30,53$ & $95,67 \pm 13,93$ & $192,00 \pm 34,27$ \\
\hline
\end{tabular}

\section{Faunisztikai eredmények}

A vizsgálat során összesen 3033 Collembola egyedet határoztunk meg. Összesen 56 fajt sikerült beazonosítani, ezek állománytípusonkénti átlagos abundancia-értékeit $1 \mathrm{~m}^{2}$-re vonatkoztatva az 2. táblázat tartalmazza. Az elökerült fajok összesen 14 családot képviselnek.

A zárt homoki tölgyesek (HTGY) nagy fajgazdagságot mutatnak, a mintaterületeken összesen 47 fajt sikerült beazonosítanunk, amelyek 14 családot képviselnek. Az ugróvillások 40\%-a az Isotomidae család fajai közül került ki, amelyek közül eudominánsnak tekinthető a Parisotoma notablis faj. Sikerült kimutatnunk az Ásotthalomról leírt Appendisotoma juliannae fajt is (Traser \& Csóka 2001), amely kizárólag a homoki tölgyesekből került elő. Az Entomobryidae családból összesen 13 faj került elő a homoki tölgyesekből. Ezek közül a teljes közösségre nézve szubdomináns az Entomobrya multifasciata. Érdekesség a mirmecofil Entomobryoides myrmecophilus faj előfordulása. A föként hemiedaphon, avarszintben illetve talajfelszínen mozgó fajok közül a Lepidocyrtus génusz négy fajjal (L. cf. arrabonicus, L. cyaneus, L. lanuginosus, L. lignorum) is jelen volt. Szubdomináns faj volt még az Onychiuridae családba tartozó Protaphorura armata is. A gömböc ugróvillások közül elökerült a Tömösváry Ödön által 1883-ban leírt Sminthurus maculatus faj egy fiatal egyede is.

A nemes nyárasokban (NNY) 7 család 19 faja került elő. Hasonlóképpen itt is az Isotomidae $(40,81 \%)$, ezt követően pedig az Entomobryidae család (26,68\%) aránya volt a legnagyobb, de $10 \%$ feletti részaránnyal képviseltek az elsősorban mélyebb rétegekben élő fajokat magukba foglaló Onychiuridae és Tullbergiidae családok.

A domináns fajok tekintetében a nemes nyárasok közössége mutat hasonlóságot a homoki tölgyesekével, azonban meglehetősen magas azoknak az akcesszórikus és rarus fajoknak a száma, amelyek itt már nem voltak megtalálhatók. Domináns fajok a Parisotoma notablis, Entomobrya multifasciata, Protaphorura 
armata, szubdomináns pedig a Mesaphorura krausbaueri. Érdemes megemlíteni, hogy a gömböc ugróvillások (Symphypleona) szinte teljesen hiányoztak ezekből az állományokból, csupán az egyébként gyakori Sphaeridia pumilis faj mindössze egyetlen egyedét sikerült megtalálnunk.

A feketefenyvesekben (FF) 8 család összesen 22 faját gyüjtöttük. A fenyvesekben is nagy részaránynyal $(29,53 \%)$ jelenik meg az Isotomidae család, de hasonlóan magas a Hypogastruridae család részaránya is $(28,47 \%)$, ami elsősorban a xerofil Xenylla brevisimilis faj tömeges előfordulásának köszönhető. Az Entomobryidae család részaránya is meghaladja a $20 \%$-ot, elsősorban a fenyvesekben is domináns Entomobrya multifasciata fajnak köszönhetően. Érdekességként említhető meg egy másik Entomobrya faj, az E. nigriventris előfordulása, amelyet Stach (1930) írt le a Tolna megyei Simontornya mellöl. Ez a xerothermofil faj a kiskunsági gyepek egyik karakterfaja (Hornung 1986), amely a sorokba ültetett, gyér aljnövényzetü fenyvesekbe is alkalmanként eljuthat. A Tullbergiidae család magas részaránya a szubdomináns, euedafikus Mesapohorura fajoknak ( $M$. critica, M. krausbaueri) köszönhető. Az Onichiuridae család részaránya ugyan csekély, de egy érdekes fajjal képviselt: a Protahorura serbica ugróvillást Loksa \& Bogojevic (1967) írták le a szerbiai Deliblát homokpusztáról.

Az akácosokban (A) 9 család összesen 23 faját sikerült kimutatni. Az akácosokban a legnagyobb egyedszám szerinti részaránnyal $(28,77 \%)$ a Tullbergiidae család képviselt (20. ábra), a közösség egyik domináns (Mesaphorura krausbaueri) és egy további szubdomináns faja ( $M$. critica) is ebböl a családból kerül ki. Azlsotomiodae családba az egyedek egynegyede tartozik, domináns faj a teljes közösségre nézve a Parisotoma notabilis, emellett előfordult még az Isotomiella minor is, amelyet az akácosokon kívül kizárólag a homoki tölgyesekben találtunk. Számottevő az Onichiuridae család részaránya is $(16,50 \%)$, a domináns Protaphorura armata mellett - kisebb egyedszámban - még további három Protaphorura faj is előkerült az akácosokból (P. aurantiaca, P. gisini, P. cancellata). Az Entomobryidae család az akácosokban is domináns Entomobrya multifasciata mellett a Lepidocyrtus génusz több fajával is képviselt. Ezek közül említést érdemel a ritkább L. nigrescens, amely eddig elsősorban hazánk lösz- és homokvidékeiről került elő (Loksa 1987, 1991, Traser \& Horváth-Szováti 2004).

2. táblázat: Az előforduló Collembola fajok átlagos abundanciája (egyed $\left./ \mathrm{m}^{2}\right)$ a vizsgált erdőállományokban HTGY - homoki tölgyes, NNY - nemes nyáras, FF - feketefenyves, A - akácos

Table 2: Collembola species spectrum and mean abundance (ind. $/ \mathrm{m}^{2}$ ) in the sampled forest types HTGY - steppe oak forests, NNY - hybrid poplar, FF - Black pine, A - Black locust

\begin{tabular}{|l|c|c|c|c|}
\hline \multicolumn{1}{|c|}{ COLLEMBOLA } & HTGY & NNY & FF & A \\
\hline Brachystomellidae & 0 & 0 & 0 & $11 \pm 11$ \\
\hline Brachystomella curvula (Gisin, 1948) & \multicolumn{5}{l|}{} \\
\hline Hypogastruridae & 0 & 0 & $44 \pm 44$ & 0 \\
\hline Ceratophysella denticulata (Bagnall, 1941) & $33 \pm 19$ & 0 & 0 & 0 \\
\hline Choreutinula inermis (Tullberg, 1871) & $133 \pm 33$ & $222 \pm 206$ & 0 & $444 \pm 183$ \\
\hline Willemia anophthalma (Börner, 1901) & $33 \pm 19$ & $22 \pm 22$ & 0 & $11 \pm 11$ \\
\hline Willemia virae (Kaprus, 1997) & $278 \pm 59$ & 0 & $1589 \pm 308$ & $178 \pm 178$ \\
\hline Xenylla brevisimilis (Stach, 1949) & 0 & 0 & $167 \pm 135$ & 0 \\
\hline Xenylla maritima (Tullberg, 1869) & & & & 0 \\
\hline Neanuridae & $67 \pm 51$ & $11 \pm 11$ & 0 & 0 \\
\hline Deutonura conjuncta (Stach, 1926) & $55 \pm 22$ & 0 & 0 & 0 \\
\hline Friesea truncata (Cassagnau, 1958) & $89 \pm 73$ & 0 & 0 & 0 \\
\hline Micranurida pygmaea (Börner, 1901) & & & & \\
\hline
\end{tabular}


A 2. táblázat (folytatás)

Table 2. (cont.)

\begin{tabular}{|c|c|c|c|c|}
\hline COLLEMBOLA & HTGY & NNY & $\mathrm{FF}$ & A \\
\hline Pratanurida cassagnaui (Rusek, 1973) & $33 \pm 33$ & 0 & 0 & 0 \\
\hline Pseudachorutes parvulus (Börner, 1901) & $33 \pm 33$ & 0 & $11 \pm 11$ & 0 \\
\hline Pseudachorutes subcrassus (Tullberg, 1871) & $100 \pm 19$ & 0 & 0 & 0 \\
\hline \multicolumn{5}{|l|}{ Odontellidae } \\
\hline Superodontella cf. empodialis (Stach, 1934) & $11 \pm 11$ & 0 & 0 & 0 \\
\hline \multicolumn{5}{|l|}{ Onychiuridae } \\
\hline Protaphorura armata (Tullberg, 1869) & $1289 \pm 393$ & $878 \pm 630$ & 0 & $767 \pm 208$ \\
\hline Protaphorura aurantiaca (Ridley, 1880) & $211 \pm 211$ & 0 & 0 & $67 \pm 67$ \\
\hline Protaphorura gisini (Haybach, 1960) & 0 & $33 \pm 33$ & $22 \pm 22$ & $11 \pm 11$ \\
\hline Protaphorura cancellata (Gisin, 1956) & $522 \pm 300$ & $11 \pm 11$ & 0 & $67 \pm 19$ \\
\hline Protaphorura cf. serbica (Loksa \& Bogojevic,1967) & 0 & 0 & $11 \pm 11$ & 0 \\
\hline \multicolumn{5}{|l|}{ Tullbergiidae } \\
\hline Doutnacia xerophila (Rusek, 1974) & $156 \pm 59$ & 0 & $22 \pm 11$ & 0 \\
\hline Mesaphorura critica (Ellis, 1976) & $378 \pm 154$ & $211 \pm 62$ & $422 \pm 219$ & $467 \pm 117$ \\
\hline Mesaphorura krausbaueri (Börner, 1901) & $645 \pm 261$ & $545 \pm 62$ & $567 \pm 184$ & $1033 \pm 135$ \\
\hline Mesaphorura macrochaeta (Rusek, 1976) & $89 \pm 40$ & $100 \pm 39$ & $122 \pm 91$ & $89 \pm 11$ \\
\hline Metaphorura affinis (Börner, 1902) & $11 \pm 11$ & 0 & 0 & 0 \\
\hline \multicolumn{5}{|l|}{ Cyphoderidae } \\
\hline Cyphoderus bidenticulatus (Parona, 1888) & $33 \pm 19$ & 0 & 0 & 0 \\
\hline \multicolumn{5}{|l|}{ Entomobryidae } \\
\hline Entomobrya corticalis (Nicolet, 1842) & $22 \pm 22$ & 0 & 0 & 0 \\
\hline Entomobrya multifasciata (Tullberg, 1871) & $1478 \pm 250$ & $1533 \pm 577$ & $1145 \pm 491$ & $611 \pm 204$ \\
\hline Entomobrya nigriventris (Stach, 1930) & 0 & 0 & $11 \pm 11$ & 0 \\
\hline Entomobrya schoetti (Stach, 1922) & $756 \pm 623$ & 0 & $56 \pm 56$ & 0 \\
\hline Entomobryoides myrmecophilus (Reuter, 1886) & $11 \pm 11$ & 0 & $11 \pm 11$ & 0 \\
\hline Lepidocyrtus cf. arrabonicus (Traser, 2000) & $389 \pm 295$ & $11 \pm 11$ & 0 & $22 \pm 22$ \\
\hline Lepidocyrtus cyaneus (Tullberg, 1871) & $78 \pm 40$ & $56 \pm 11$ & 0 & $67 \pm 67$ \\
\hline Lepidocyrtus lanuginosus (Gmelin, 1788) & $355 \pm 91$ & $33 \pm 19$ & $22 \pm 22$ & $33 \pm 19$ \\
\hline Lepidocyrtus lignorum (Fabricius, 1793) & $733 \pm 171$ & 0 & $44 \pm 29$ & 0 \\
\hline Lepidocyrtus nigrescens (Szeptyczki, 1967) & 0 & 0 & 0 & $33 \pm 19$ \\
\hline \multicolumn{5}{|l|}{ Entomobryidae } \\
\hline Pseudosinella alba (Packard, 1873) & 0 & 0 & 0 & $22 \pm 22$ \\
\hline Pseudosinella sexoculata (Schött, 1902) & $100 \pm 67$ & 0 & 0 & $11 \pm 11$ \\
\hline Pseudosinella cf. wahlgreni (Börner, 1907) & $133 \pm 33$ & $11 \pm 11$ & $22 \pm 11$ & 0 \\
\hline Orchesella cincta (Linnaeus, 1758) & $78 \pm 49$ & $33 \pm 33$ & $33 \pm 33$ & 0 \\
\hline Orchesella multifasciata (Stscherbakow, 1898) & $11 \pm 11$ & 0 & 0 & 0 \\
\hline Orchesella spectabilis (Tullberg, 1871) & $11 \pm 11$ & 0 & 0 & 0 \\
\hline
\end{tabular}


A 2. táblázat (folytatás)

Table 2. (cont.)

\begin{tabular}{|c|c|c|c|c|}
\hline COLLEMBOLA & HTGY & NNY & FF & A \\
\hline \multicolumn{5}{|l|}{ Isotomidae } \\
\hline Appendisotoma franzi (Haybach, 1962) & $267 \pm 70$ & 0 & $44 \pm 29$ & 0 \\
\hline Appendisotoma juliannae (Traser, Thibaud \& Najt, 1993) & $100 \pm 33$ & 0 & 0 & 0 \\
\hline Cryptopygus bipunctatus (Axelson, 1903) & $267 \pm 19$ & 0 & 0 & 0 \\
\hline Folsomia manolachei (Bagnall, 1939) & $111 \pm 29$ & $11 \pm 11$ & 0 & 0 \\
\hline Folsomides parvulus (Stach, 1922) & 0 & 0 & $22 \pm 22$ & 0 \\
\hline Isotomiella minor (Schäffer, 1896) & $667 \pm 203$ & 0 & 0 & $100 \pm 100$ \\
\hline Parisotoma notabilis (Schäffer, 1896) & $4255 \pm 737$ & $2545 \pm 680$ & $1800 \pm 669$ & $1311 \pm 111$ \\
\hline Proisotoma minuta (Tullberg, 1871) & $645 \pm 267$ & $11 \pm 11$ & 0 & 0 \\
\hline \multicolumn{5}{|l|}{ Tomoceridae } \\
\hline Tomocerus sp. juv & $11 \pm 11$ & 0 & 0 & 0 \\
\hline \multicolumn{5}{|l|}{ Bourletiellidae } \\
\hline Fasciosminthurus strigatus (Stach, 1922) & $22 \pm 11$ & 0 & $78 \pm 78$ & 0 \\
\hline \multicolumn{5}{|l|}{ Katiannidae } \\
\hline Sminthurinus aureus (Lubbock, 1862) & $55 \pm 40$ & 0 & 0 & 0 \\
\hline \multicolumn{5}{|l|}{ Sminthurididae } \\
\hline Sphaeridia pumilis (Krausbauer, 1898) & $622 \pm 219$ & $11 \pm 11$ & 0 & $100 \pm 58$ \\
\hline \multicolumn{5}{|l|}{ Sminthuridae } \\
\hline Sminthurus maculatus (Tömösváry, 1883) & $11 \pm 11$ & 0 & 0 & 0 \\
\hline Spatulosminthurus flaviceps (Tullberg, 1871) & $22 \pm 22$ & 0 & 0 & 0 \\
\hline Lipothrix lubbocki (Tullberg 1872) & $133 \pm 70$ & 0 & $78 \pm 49$ & $56 \pm 11$ \\
\hline
\end{tabular}

\section{Közösségi ökológiai eredmények}

A vizsgált autochton (homoki tölgyes) és allochton (tájidegen fafajú) állományok Collembola-közösségeinek fontosabb paramétereit a 3. táblázat tartalmazza.

3. táblázat: A vizsgált állománytípusok ugróvillás-közösségeinek fontosabb karakterisztikái (átlag $\pm S E)$.

HTGY - homoki tölgyes, NNY - nemes nyáras, FF - feketefenyves, $A$ - akácos; *kumulatív fajszám

Table 3: Mean values of collembola community characteristics in the sampled forest types (mean $\pm S E$ ). HTGY-steppe oak forests, $N N Y$ - hybrid poplar, FF-Black pine, A-Black locust; " ${ }^{2}$ umulative species richness

\begin{tabular}{|l|c|c|c|c|}
\hline & HTGY & NNY & FF & A \\
\hline Fajszám $(S)$ & $35,67 \pm 0,67\left({ }^{*} 47\right)$ & $11,33 \pm 2,03\left({ }^{*} 19\right)$ & $12,67 \pm 0,33\left({ }^{*} 22\right)$ & $14,67 \pm 1,20\left({ }^{*} 23\right)$ \\
\hline Abundancia $(A)($ egyed/m²) & $15544 \pm 2139$ & $6289 \pm 1820$ & $6333 \pm 918$ & $5522 \pm 405$ \\
\hline Shannon index $\left(H^{\prime}\right)$ & $2,698 \pm 0,083$ & $1,567 \pm 0,157$ & $1,807 \pm 0,032$ & $2,129 \pm 0,062$ \\
\hline Egyenletesség $(J)$ & $0,755 \pm 0,026$ & $0,655 \pm 0,049$ & $0,712 \pm 0,019$ & $0,795 \pm 0,005$ \\
\hline Közösségi dominancia index $(K D I)$ & $40,34 \pm 2,80$ & $67,14 \pm 6,58$ & $58,50 \pm 2,77$ & $45,07 \pm 1,83$ \\
\hline
\end{tabular}


Mind az átlagos és a kumulatív fajszámot (S) tekintve a homoki tölgyesek bizonyultak a legfajgazdagabbnak. Ha a teljes vizsgálati területen gyüjtött Collembola fajok számát (56) 100\%-nak tekintjük, akkor a homoki tölgyes állományokban 84\%-a (47 faj) fordult elő. A fajokban legszegényebb állománytípust a nemes nyárasok jelentették, itt mindössze 19 faj (a teljes területen kimutatott fajkészletnek csupán 34\%-a) került elő. A feketefenyvesekben előkerült fajok száma (22), bár a nemes nyárasokénál magasabb, a homoki tölgyesekkel összehasonlítva még mindig alacsonynak mondható, s a teljes fajkészletnek mindössze 39\%-a. Az akácosok kumulált fajszáma nem éri el a homoki tölgyesekben talált fajok számának felét sem, a teljes fajkészletnek mindössze 41\%-a volt ezekben az állományokban kimutatható.

A legnagyobb átlagos ugróvillás-abundancia $(A)$ szintén a homoki tölgyesek talajában volt jellemző: az idegenhonos ültetvényekkel összehasonlítva közel háromszoros az $1 \mathrm{~m}^{2}$-re vonatkoztatott egyedszám a homoki tölgyesekben.

A Shannon-diverzitás $\left(H^{\prime}\right)$ legnagyobb átlagos értéke is a homoki tölgyesekre jellemző, ezt követi sorrendben az akácos, feketefenyves és végül a nemes nyáras diverzitása. Ezt igazolják a Rényi-féle diverzitás profilok (2. ábra) is, amelyek a Shannon-diverzitáson kívül a fajszámot és a Simpson-diverzitást is figyelembe veszik. A profilok nem metszik egymást, ezért a közösségek rangsorolhatók, melynek alapján a homoki tölgyes $\rightarrow$ akácos $\rightarrow$ feketefenyves $\rightarrow$ nemes nyáras sorrend állítható fel.

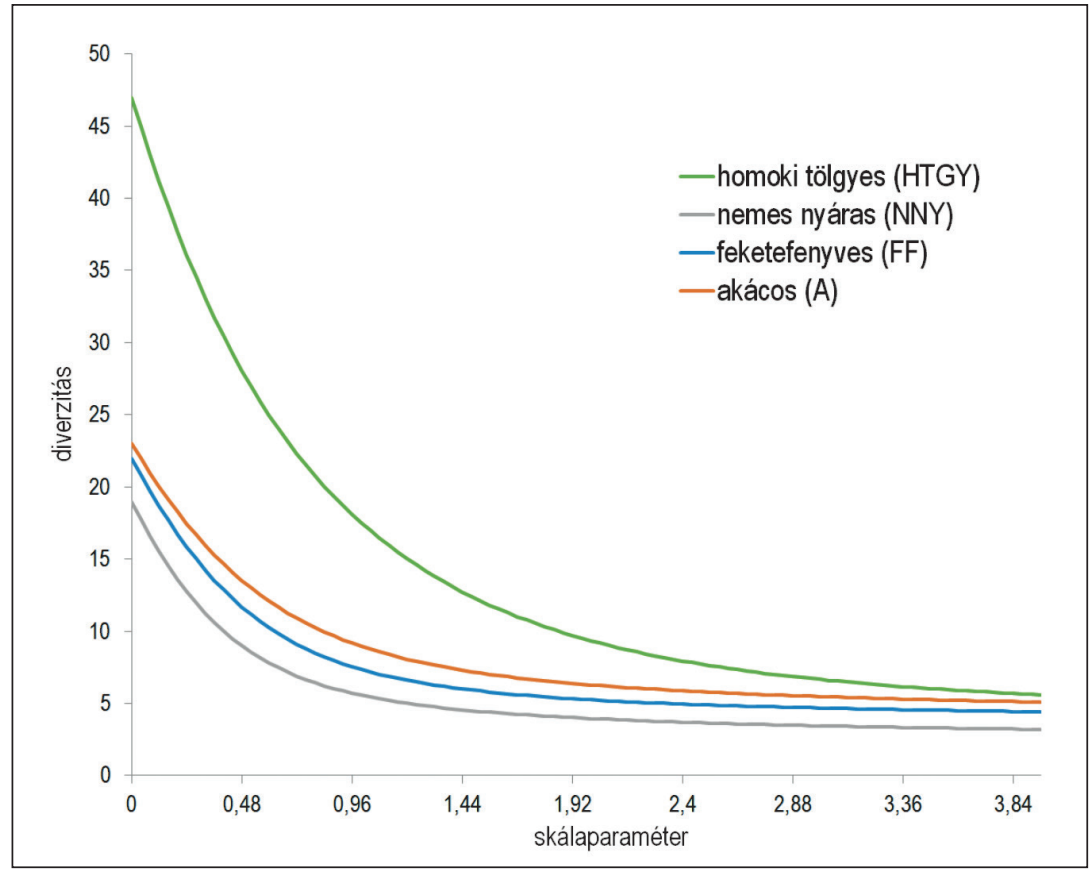

2. ábra: A vizsgált erdőállományok Collembola-közösségeinek diverzitási profiljai Figure 2: Diversity profiles of Collembolan communities in the sampled forest types

A kiegyenlítettség $(\mathrm{J})$ legmagasabb átlagos értéke az akácosokra volt jellemző, míg legalacsonyabb a kiegyenlítettség a nemes nyárasok Collembola-közösségeinél.

A közösségi dominancia-index (KDI) legnagyobb átlagos értéke a nemes nyárasoknál adódott, amely utal az itt található ugróvillás-közösségek kedvezőtlen szerkezetére, kiegyenlítetlen viszonyaira is. Az index legkisebb átlagos értékét a homoki tölgyesek közösségeinél kaptuk. 


\section{A talajparaméterek és a Collembola-közösségek összefüggései}

Az egyes talajparaméterek hatását vizsgálva az ugróvillás-közösségek föbb jellemzőire (fajszám, diverzitás, abundancia) két szoros, szignifikáns összefüggést kaptunk. $A C / N$ arány növekedése szignifikáns ( $r=0,71$; $\mathrm{F}=10,44, p<0,05)$, pozitív hatással bír az ugróvillás-abundanciára. A magas $\mathrm{C} / \mathrm{N}$ arány a homoki tölgyesekre volt jellemző, és itt volt a legmagasabb az átlagos abundancia is. Előbbi összefüggés mellett a humusztartalom $(\mathrm{H} \%)$ mutatott még erős-közepes, szignifikáns kapcsolatot $(r=0,61 ; F=5,98, p<0,05)$ a Collembola-közösségek diverzitásával. Magas humusztartalom az őshonos homoki tölgyesek mellett az akácosok talajára is jellemző volt, amely állományok talaját - a többi idegenhonos ültetvényekkel összevetve - viszonylag magasabb diverzitású ugróvillás-közösségek népesítik be.

Az ordinációs elemzések emellett komplexebb összefüggések feltárását is lehetővé tették. $A$ kanonikus korreszpondencia analízis (CCA) eredményét a 3. ábra szemlélteti. A Monte Carlo permutációs teszt igazolta az első két tengely szignifikanciáját ( $p<0,05)$, amelyek együttesen $65,72 \%$-át magyarázzák a varianciának. Az első tengellyel 42,44\%-ot, míg a második tengellyel további 23,28\%-ot fedünk le. Amint az a 3. ábrán megmutatkozik, az első tengelyt a talaj pH határozza meg, de nem elhanyagolható a kálium- és humusztartalom hatása sem. A második tengelyt a talaj nitrogén- és foszfortartalma határozza meg jobban.

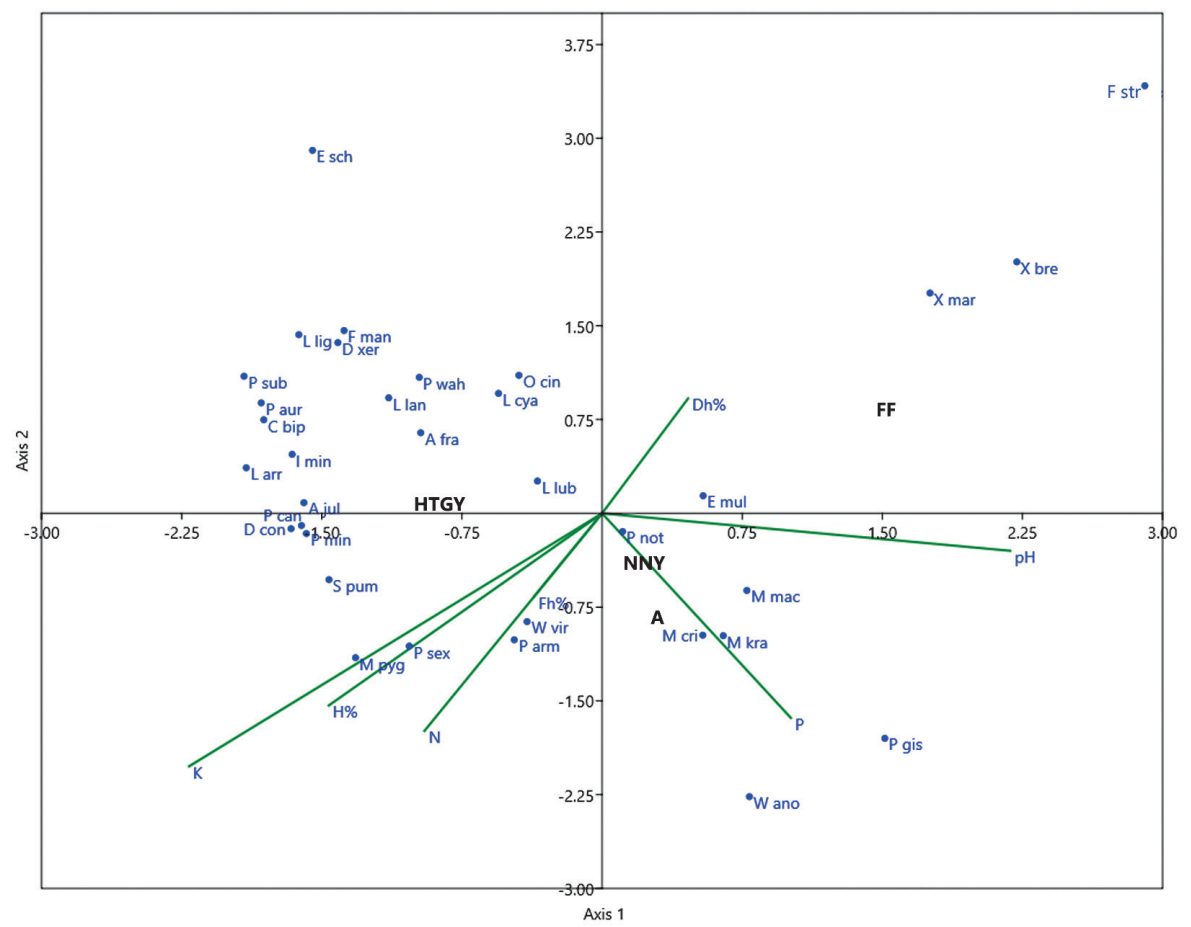

3. ábra: Az ugróvillás fajok, erdőtípusok és a háttérváltozók elhelyezkedése a CCA ordináció első két tengelye mentén (a fajok a tudományos név 1+3 betüs kódjával vannak feltüntetve)

Figure 3: Ordination biplot of CCA with Collembola species, forest types and selected soil variables. Collembola species name abbreviations consist of the initial letter of the genus name followed by the first three letters of species

Az elsősorban nyílt területekre jellemző, leginkább xerothermofil fajok (Xenylla maritima, $X$. brevisimilis, Friesea truncata) a feketekenyvesekhez kötődnek, amelyek az enyhén lúgos hatás miatt is az első tengely pozitív irányában találhatók. A feketefenyvesek mellett a nemes nyárasok és az akácosok is az első ten- 
gely pozitív oldalán helyezkednek el, a hozzájuk leginkább kötődő, a kedvezőtlenebb körülményeket is elviselő fajokkal. Ezek elsősorban a Tullbergiidae családból kerülnek ki (Mesaphorura critica, M. krausbaueri, M. macrochaeta). Az első tengely negatív oldalán találjuk a homoki tölgyes mintaterületeket, amelyekre az enyhén savanyú talaj mellett a nagyobb humusz, illetve széntartalom is jellemző volt. Emiatt az acidofil fajok (pl. Micranurida pygmaea) mellett olyan fajokat találunk, amelyek a legtöbbször zárt erdők, magas humusztartalmú talajában fordulnak elő (Protaphorura cancellata, Appendisotoma juliae, Isotomiella minor, Cryptopygus bipunctatus, Proisotoma minuta, Pseudosinella cf. wahlgreni). A leggyakoribb, minden élőhelyen domináns fajok, mint a Parisotoma notabilis és az Entomobrya multifasciata centrális helyzetüek.

\section{MEGVITATÁS}

Az ember tájhasználata - s ezen belül az erdőgazdálkodás is - jelentősen átformálta a természetes tájakat, erdeinket (Traser \& Horváth-Szováti 2004). A drasztikus átalakítások közé tartozik a tájidegen, nem őshonos fafajok telepítése a természetes vagy természetszerű erdők, gyepek helyén. Ezeknek a markáns folyamatoknak számos természetvédelmi és egyben érdekes talajbiológiai vonatkozásai is vannak. Az idegenhonos, ültetvényszerű faállományok talajlakó faunája is alapvetően szegényebb, mint az őshonos fafajok alkotta állományoké (Lindenmayer et al 2003). A Kiskunságban, zárt homoki tölgyesekben és az azok helyére teleptett idegenhonos faültetvényekben végzett talajfaunisztikai kutatásunk eredményei is ezt igazolják. Míg a teljes vizsgálati területen gyüjtött Collembola fajok számát 100\%-nak tekintve a homoki tölgyes állományokban a fajok 84\%-a előfordult, ez a százalékos arány az akácosokban $41 \%$, a feketefenyvesekben 39\%, a nemes nyárasokban pedig mindössze $34 \%$ volt. A vizsgálati eredményekből azonban nem minden esetben szabad olyan következtetéseket levonni, amelyek határozottak és messzemenők, illetve irreverzibilis folyamatokra utalnak, de vitathatatlanul vannak olyan faunisztikai és közösségi-ökológiai eredmények, amelyeket további vizsgálatsorozatokkal érdemes alátámasztani. A területekről az alábbiak szerint elmondható, hogy az állományalkotó fafajok erőteljes hatással vannak a talajparaméterekre a talajokban zajló folyamatok megváltoztatásával. Hasonló, negatív összefüggést állapított meg Hågvar (1987) a talajleromlás foka és az ugróvillás közösségek fajszáma, abundanciája között. A szakirodalomban fellelhető ezzel szemben olyan példa, amelyben az ugróvillás-közösségek ellenállnak a különböző degradációs folyamatoknak a nehézfémsók felhalmozódása és talajkémhatás változtató hatása során (Bengtsson \& Rundgren 1988).

Az Duna-Tisza közi homokhátság területén megtalálható legfontosabb idegenhonos, adventív, gazdaságilag és területarányosan jelentős fafajaink a fehér akác (Robinia pseudoacacia), a feketefenyő (Pinus nigra), valamint a különböző nemes nyár fajták. Ezek a fafajok hazánkban számos termőhelyen és területen megtalálhatók, ahol hosszú évtizedes jelenlétük, szerves anyagaikból származó bomlástermékeik megváltoztatták a talaj egyes paramétereit, az élővilágát, az eredeti növénytársulás egyik alappillérét (Ónodi 2016).

Az erdei- és feketefenyő is erőteljes hatással vannak a talajfauna összetételére egyes talajparaméterek formálása révén. A talajra hulló, vastagon felhalmozódó, nehezen és lassan bomló, gyantás fenyő tűlevelek bomlása közben savas jellegü vegyületek, terpének, gyürüsláncú, fenolos jellegü molekulák keletkeznek és szabadulnak fel, amelyek a meszes homok bázikus tulajdonságát tompítják, semlegessé majd idővel gyengén savanyúvá téve azt. A fenolos jellegü vegyületek biológiai gátlóanyagokként a talajba bemosódva csírázásgátlókként fejtik a hatásukat (Cseresnyés \& Tamás 2014). A fenyöültetvényekben ezért a lebontás hatékonysága a talajfauna által jóval kisebb hatékonyságú, mint a lombos állományokban (Dunger \& Voigtländer 2009). Tengerparti fenyő (Pinus pinaster) ültetvényekben végzett vizsgálataik alapján Arbea \& Jordana (1985), valamint Gama et al $(1994,1995)$ arra az eredményre jutottak, hogy a tűavar átalakító hatásának következtében az ugróvillások egyedszám-csökkenése mellett számos faj el is tűnik a területről. Hazai vizsgálatok során hasonló következtetésre jutottak. Telepített erdei- és feketefenyvesek talajában a Collembola fajszám és abundancia jelentősen 
alulmaradt a természetszerü, fehér nyárral elegyes kocsányos tölgy állományokkal szemben (Traser \& Csóka 2001). Winkler \& Tóth (2012) nyugat-dunántúli erdei- és feketefenyő ültetvényekben végzett vizsgálatai is hasonló eredményre vezettek. Megállapították azonban, hogy a fenyvesek talajában még szép számmal találhatók olyan fajok is, amelyek a természetes társulások (molyhos tölgyesek, sztyeprétek) talajában is előfordulnak. Így a talajdegradációs folyamatok még nem tekinthetők visszafordíthatatlannak, és egy letermelést követő visszagyepesítés vagy őshonos fafajjal való felújitás pozitív irányú változásokat is hozhat.

Az akác hatását - hatalmas térfoglalása ellenére - kevesen vizsgálták a talajfaunára nézve. Rice et al (2004) vizsgálatai alapján az akác nitrogénfixáló képességével jelentősen megváltoztatja a talajok nitrogénforgalmát. Fájában nagy mennyiségben találunk nehezen bomló poliszacharidokat, lignint és szerves savakat, amelyek nem járulnak hozzá bomlásuk során a talaj humusztartalmának növeléséhez, tápanyagtartalmát sem növelik a talajnak (Kurt \& Erteld 1952). Levelének fitotoxin tartalma idézi elő a lombjának bomlásából származó allelopatikus hatást a többi növény számára, ezzel elősegítve gyökérsarjainak felverődést a növőtér biztositásával. De befolyásolja a talaj szerkezetének milyenségét és átjárhatóságát, mert a lágyszárú növények hiányában elmarad a lágyszárúak gyökerei által okozott talajlazítás és a kedvezőbb vízáteresztő képesség kialakulása. Különösen erősen érinti ez a tápanyagszegény homoktalajokat, emellett befolyásolja az állományai fényviszonyait és a mikroklímáját, így a talaj mikrofaunáját is. Ez a fafaj másodlagos metabolitokat (pl. toxalbuminokat, robint és phasin) képes előállítani és felszabadítani, amelyek gátló hatással lehetnek a talajlakó állatok fehérjeszintézisére (Hui et al 2004, Rahmonov 2009, Lazzaro et al 2018). Ezt egyes ugróvillás fajok kevésbé tolerálják (Hopkin 1985). Harta et al (2018) akác telepítések ugróvillás faunáját vizsgálva kisebb fajszámot és diverzitást mutatott ki hasonló korú kocsánytalan tölgyes telepítéssel összehasonlítva, az abundancia azonban az akácosokban volt - ha nem is jelentősen - magasabb. A kiskunsági vizsgálatok azt mutatták, hogy az akácosok ugróvillás-diverzitása, bár elmarad a homoki tölgyesekétöl, a nyemes nyárasokkal és feketefenyvesekkel összehasonlítva kedvezőbbnek mondható. Ez elsősorban az akácosok talajának magasabb humusztartalmának köszönhető, amely erős-közepes pozitív korrelációt mutatott a Collembola diverzitással.

Nemes nyárasok talajbiológiai vonatkozásairól nagyon kevés információ áll rendelkezésre. Ezek a gyorsan növő nemesített fajták/hibridek köztudottan úgymond „kizsarolják” a talajt, ami megmutatkozott a kiskunsági talajparaméter-eredményeknél is. Ezen kívül a legalacsonyabb humusztartalom is a nemes nyárasok talajára volt jellemző, amely az előbbiekben említett összefüggés szerint alacsony Collembola-diverzitást eredményez. Hazánkban Traser (2003) végzett talajzoológiai vizsgálatokat nemes nyárasokban. A Hanságban végzett kutatás is alátámasztotta, hogy a nemes nyárasok fajszegényebb ugróvillás-közösségekkel jellemezhetők, mint a területen őshonos, egykor nagy kiterjedésben megtalálható égerállományok.

\section{ÖSSZEFOGLALÁS}

Összességében elmondható, hogy az egykori homoki tölgyes állományok lecserélése idegenhonos fafajok ültetvényeivel mérhető változásokat hozott mind a talajparaméterek, mind pedig a talajlakó mezofauna vonatkozásában. Az ugóvillás-közösségek paramétereiben megmutatkozó szignifikáns csökkenés egyértelműen jelzi a talajdegradáció mértékét.

\section{KÖSZÖNETNYILVÁNÍTÁS}

A kutatás az Innovációs és Technológiai Minisztérium ÚNKP-19-2-I kódszámú Új Nemzeti Kiválóság Programjának szakmai támogatásával készült. 


\section{FELHASZNÁLT IRODALOM}

Arbea J.I. \& Jordana R. 1985: Efecto de una repoblación con coníferas en un robledal de Navarra sobre los colémbolos edáficos. Boletim da Sociedade Portuguesa de Entomologia Supl. 1(2): 277-286.

Babenko A.B., Chernova N.M., Potapov M.B. \& Stebaeva M.B. 1994: Collembola of Russia and adjacent countries: Family Hypogastruridae. Nauka, Moskow.

Bacsó A., Dezső I., Maul F., Stefanovics P. \& Tusz Zs. 1972: Talajtani gyakorlatok. Egyetemi jegyzet, Agrártudományi Egyetem Mezőgazdaságtudományi Kar, Gödöllö.

Bartha D. 2001: Veszélyeztetett erdőtársulások Magyarországon. WWF Füzetek 18. Budapest.

Bretfeld G. 1999: Symphypleona. In Dunger W. (ed), Synopses on Palaearctic Collembola. Vol. 2. Abhandlungen und Berichte des Naturkundemuseums Görlitz 71(1): 1-318.

Bengtsson G. \& Rundgren S. 1988: The Gusum Case: A Brass Mill and the Distribution of Soil Collembola, Canadian Journal of Zoology 66: 1518-1526.

Buzás I. (ed) 1988: Talaj- és agrokémiai vizsgálati módszerkönyv 2. Budapest, Mezőgazdasági Kiadó.

Cseresnyés I. \& Tamás J. 2014: Evaluation of Austrian pine (Pinus nigra) plantations in Hungary with respect to nature conservation - a review. Tájökológiai Lapok 12(2): 267-284.

Dányi L. \& Traser G. 2008: An annotated checklist of the springtail fauna of Hungary (Hexapoda: Collembola). Opuscula Zoologica 38: 3-82.

Deharveng L. 1982: Cle de determination des genres de Neanurinae (Collembola) d'Europe et la region Mediterraneenne, avec description de deux nouveaux genres. Trav. Lab. Ecobiol. Arthr. Edaph. 3: 7-13.

Dunger W. \& Voigtländer K. 2009: Soil fauna (Lumbricidae, Collembola, Diplopoda and Chilopoda) as indicators of soil ecosubsystem development in post-mining sites of eastern Germany - a review. Soil Organisms 81(1): 1-51.

Egnér H.A.N.S., Riehm H. \& Domingo W.R. 1960: Untersuchungen über die chemische Bodenanalyse als Grundlage für die Beurteilung des Nährstoffzustandes der Böden. II. Chemische Extraktionsmethoden zur Phosphor-und Kaliumbestimmung. Kungliga Lantbrukshögskolans Annaler 26: 199-215.

Fjellberg A. 1980: Identification keys to Norwegian Collembola. Norsk Entomol. Forening 1-152.

Fjellberg A. 1998: The Collembola of Fennoscandia and Denmark. Part I.: Poduromorpha. Fauna Entomologica Scandinavica 35: 1-184.

Gama M.M., Vasconcelos T.M. \& Sousa J.P. 1994: Collembola diversity in Portuguese autochthonous and allochthonous forests. Acta Zoologica Fennica 195: 44-46.

Gama M.M., Sousa J.P. \& Vasconcelos T.M. 1995: Comparison of Collembolan populations structure from Portuguese forests of Pinus pinaster AITON and Eucalyptus globulus LABILL. Bulletin Entomoloque de Pologne 64: 71-89.

Hammer Ř., Harper D.A.T. \& Ryan P.D. 2001: PAST: Paleontological Statistics Software Package for Education and Data Analysis. Palaeontologia Electronica 4: 1-9.

Hågvar S. 1987: Why do collemboles and mites react to changes in soil acidity? Entomologiske Meddelelser 55(2-3): $115-119$.

Harta I., Winkler D. \& Füleky Gy. 2018: Újraerdősités hatása a talajlakó mezofaunára (Collembola) egykori szántóföldi mütrágyázási tartamkísérleti területen. Erdészettudományi Közlemények 8(2): 83-97.

Hopkin S.P. 1997: Biology of the Springtails (Insecta: Collembola). University Press, Oxford.

Hornung E.H. 1986: Check list of Collembola on a sandy grassland (Kiskunság National Park, Hungary). Acta Universitatis Szegediensis, Acta Biologica 32(1-4): 137-139.

Hui A., Marraffa J.M. \& Stork C.M. 2004. A rare ingestion of the Black Locust tree. Journal of Toxicology. Clinical Toxicology 42(1): 93-95. DOI: 10.1081/CLT-120028752

Jordana R. 2012: Capbryinae \& Entomobryini. In: Dunger W. \& Burkhardt U. (eds): Synopses on Palaearctic Collembola. Vol. 7/1. Soil Organisms 84: 1-390. 
Jordana R., Arbea J.I. \& Carlos Simón M.J.L. 1997: Collembola, Poduromorpha. Fauna Iberica, Vol. 8. Museo National de Ciencias Naturales, Madrid. 1-807.

Klimetzek D. 1992: Schädlingsbelastung der Waldbäume in Mitteleuropa und Nordamerika. Forstwissenschaftliches

Centralblatt 111(1): 61-69. DOI: 10.1007/BF02741659

Krebs C.J. 1978: Ecology: The Experimental Analysis of Distribution and Abundance. $6^{\text {th }}$ ed. Benjamin Cummings, San Francisco.

Kurt G. \& Erteld W. 1952: Die Robinie (falsche Akazie) und ihr Holz. Deutscher Bauernverlag, Berlin.

Lazzaro L., Mazza G., d'Errico G., Fabiani A., Giuliani C. Inghilesi A.F., Lagomarsino A., Landi S., Lastrucci L., Pastorelli

R., Roversi P.F., Torrini G., Tricarico E. \& Foggi B. 2018: How ecosystems change following invasion by Robinia pseudoacacia: Insights from soil chemical properties and soil microbial, nematode, microarthropod and plant communities. Science of the Total Environment 622-623: 1509-1518. DOI: 10.1016/j.scitotenv.2017.10.017

Lesznyák J. 1993: Emlékezés az alföldfásitás évszázadára. Erdészeti Lapok 128(5): 138-145.

Lindenmayer D.B., Hobbs R.J. \& Salt D. 2003: Plantation forests and biodiversity conservation. Australian Forestry 66(1):

62-66. DOI: 10.1080/00049158.2003.10674891

Loksa I. 1987: Collembola from the Kiskunság National Park. In: Mahunka S. (ed): The fauna of the Kiskunság National Park. Akadémiai Kiadó, Budapest, 78-80.

Loksa I. 1991: The Collembola fauna of the Bátorliget Nature Reserves (NE Hungary). In: Mahunka S. (ed): The Bátorliget Nature Reserves - after forty years. Studia Naturalia 1(1): 269-277.

Loksa I. \& Bogojević J. 1970: Einige interessante Collembolen-Arten aus der Sandwüste von Deliblat, Jugoslawien. Opuscula Zoologica 10: 125-142.

Molnár Zs. \& Kun A. (eds) 2000: Alföldi erdőssztyepp maradványok Magyarországon. WWF Füzetek 15.

Ónodi G. 2016: Az idegenhonos, illetve inváziós fafajok élőhelyformáló hatásai. Erdészettudományi Közlemények 6(2): 101-113.

Pielou E.C. 1966: The measurement of diversity in different types of biological collections. Journal of Theoretical Biology 13: 131-144. DOI: 10.1016/0022-5193(66)90013-0

Pinto C., Sousa J.P., Graça M.A. \& Da Gama M.M. 1997: Forest soil Collembola. Do tree introductions make a difference? Pedobiologia 41: 207-214.

Pomorski R.J. 1998: Onychiurinae of Poland (Collembola: Onychiuridae). Genus (Supplement), Polish Taxonomical Society, Wrockaw, 1-201.

Potapov M. 2001: Synopses on Palaearctic Collembola: Isotomidae. Abhandlungen und Berichte des Naturkundemuseums Görlitz 73(2): 1-603.

Rahmonov O. 2009: The chemical composition of plant litter of black locust (Robinia pseudoacacia L.) and its ecological role in sandy ecosystems. Acta Ecologica Sinica 29:4. 237-243. DOI: 10.1016/j.chnaes.2009.08.006.

Rice S.K., Westerman B. \& Federici R. 2004: Impacts of the exotic, nitrogen-fixing Black locust (Robinia pseudoacacia) on nitrogen-cycling in a pine-oak ecosystem. Plant Ecology 174(1): 97-107. DOI: 10.1023/B:VEGE.0000046049.219 $00.5 \mathrm{a}$

Sousa J.P. \& Gama M.M. 1994: Rupture in a Collembola community structure from a Quercus rotundifolia Lam. forest due to reafforestation with Eucalyptus globulus Labill. European Journal of Soil Biology 30(2): 71-78.

Sousa J.P., Vingada J.V., Barrocas H. \& Da Gama M.M. 1997: Effects of introduced exotic tree species on Collembola communities: the importance of management techniques. Pedobiologia 41: 166-174.

Stach J. 1930: Apterygoten aus dem nördlichen und östlichen Spanien. Abhandlungen herausgegeben von der Senckenbergischen Naturforschenden Gesellschaft 42: 3-83.

ter Braak C.J.F. \& Šmilauer P. 2002: CANOCO Reference Manual and Canodraw for Windows User's Guide: Software for Canonical Community Ordination (Version 4.5). Microcomputer Power, Ithaca, New York.

Thibaud J.M., Shulz H.J. \& Da Gama M.M. 2004: Synopses on Palaearctic Collembola: Hypogastruridae. Abhandlungen und Berichte des Naturkundemuseums Görlitz 75(2): 1-603. 
Tóthmérész B. 1998: Kvantitatív ökológiai módszerek a skálafüggés vizsgálatára. In: Fekete G. (ed): A közösségi ökológia frontvonalai. Scientia Kiadó. Budapest. 145-160.

Tömösváry Ö. 1883: Magyarországban talált Smynthurus fajok. Természetrajzi füzetek 7: 31-38.

Traser Gy. 2003: Hansági nemesnyár és éger erdők ugróvillás (Insecta: Collembola) faunája. Magyar Biológiai Társaság, Budapest. III. Kárpát-medencei Biológiai Szimpózium kiadványa. 153-157.

Traser Gy. \& Csóka Gy. 2001: A mezofauna - Insecta: Collembola - ásotthalmi fenyő- és tölgyerdők talajában. Erdészeti Kutatások 90: 231-240.

Traser Gy. \& Horváth-Szováti E. 2004: Táj-hasznosítás hatása a talajfaunára: ugróvillás (Parainsecta: Collembola) közösségek diverzitása Csévharaszton. Alföldi Erdőkért Egyesület, Kecskemét, 51-62.

Tullgren A. 1918: Ein sehr einfacher Ausleseapparat für terricole Tierformen. Zeitschrift für Angewandte Entomologie 4(1): 149-150.

Weiner W.M. 1996: Generic revision of Onychiurinae (Collembola: Onychiuridae) with a cladistic analysis. Annales de la Société Entomologique de France 32(2): 163-200.

Winkler D. \& Tóth V. 2012: Effects of Afforestation with Pines on Collembola Diversity in the Limestone hills of Szárhalom (West Hungary). Acta Silvatica et Lignaria Hungarica 8: 9-20. DOI: 10.2478/v10303-012-0001-8

Zimdars B. \& Dunger W. 1994: Tullbergiinae. In: Dunger W. (ed): Synopses on Palaearctic Collembola. Vol.: I. Abhandlungen und Berichte des Naturkundemuseums Görlitz, 68:3-4. 1-71.

Érkezett: 2020. szeptember 08.

Közlésre elfogadva: 2020. október 20. 